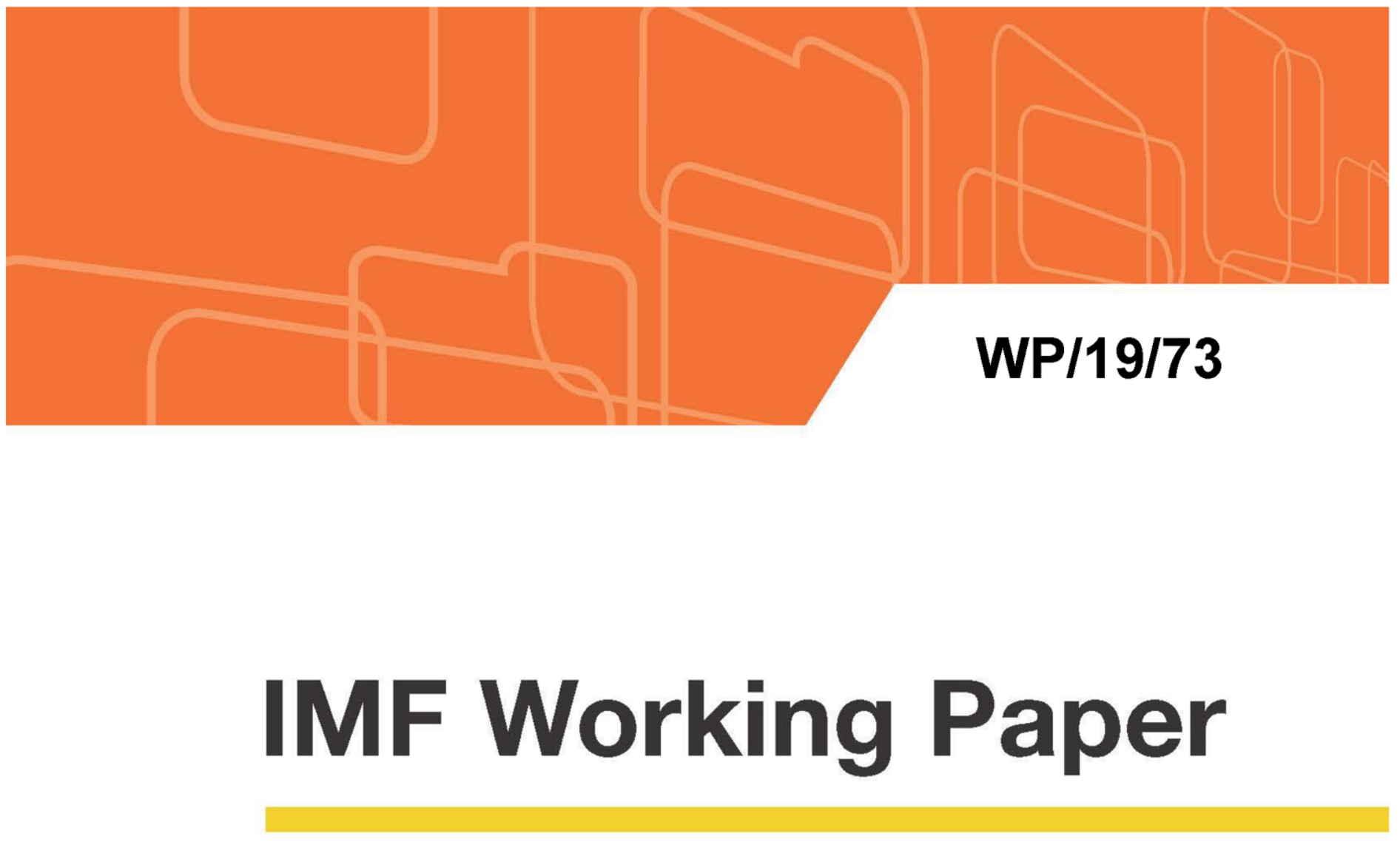

\title{
NAFTA to USMCA: What is Gained?
}

by Mary E. Burfisher, Frederic Lambert, and Troy Matheson

IMF Working Papers describe research in progress by the author(s) and are published to elicit comments and to encourage debate. The views expressed in IMF Working Papers are those of the author(s) and do not necessarily represent the views of the IMF, its Executive Board, or IMF management. 


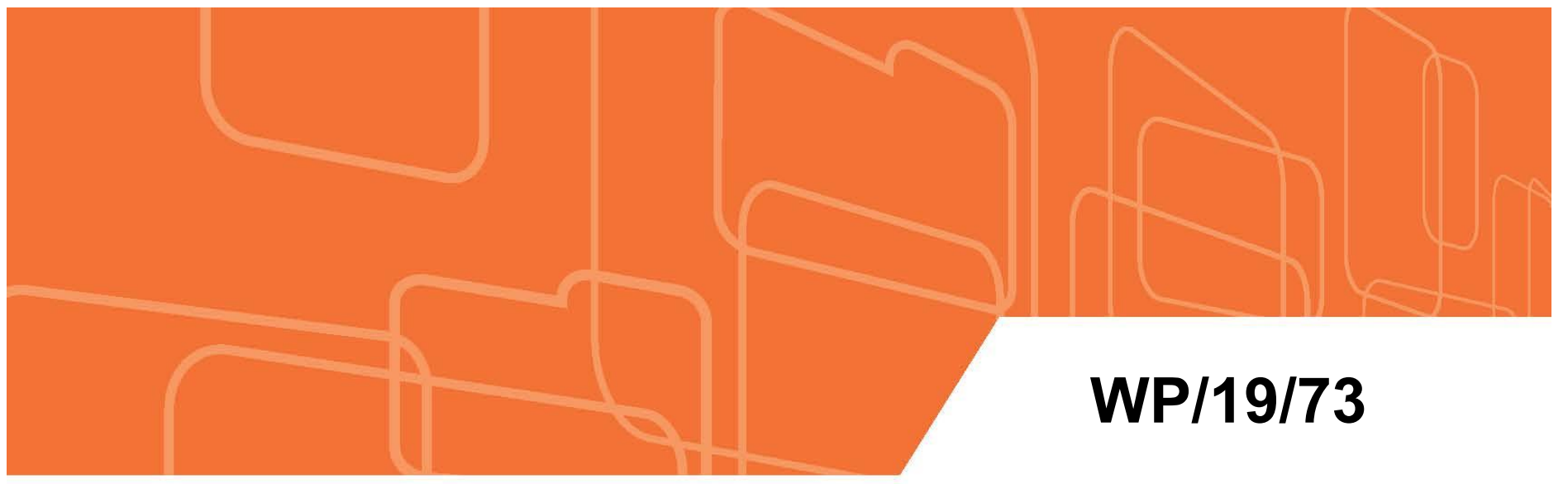

\section{IMF Working Paper}

\section{NAFTA to USMCA: What is Gained?}

by Mary E. Burfisher, Frederic Lambert, and Troy Matheson

IMF Working Papers describe research in progress by the author(s) and are published to elicit comments and to encourage debate. The views expressed in IMF Working Papers are those of the author(s) and do not necessarily represent the views of the IMF, its Executive Board, or IMF management. 


\title{
IMF Working Paper
}

Western Hemisphere Department

NAFTA to USMCA: What is Gained?'

\section{Prepared by Mary E. Burfisher, Frederic Lambert, and Troy Matheson}

Authorized for distribution by Cheng Hoon Lim

March 2019

\section{IMF Working Papers describe research in progress by the author(s) and are published to elicit comments and to encourage debate. The views expressed in IMF Working Papers are those of the author(s) and do not necessarily represent the views of the IMF, its Executive Board, or IMF management.}

\begin{abstract}
The United States - Mexico - Canada Agreement (USMCA) was signed on November 30, 2018 and aims to replace and modernize the North-American Free Trade Agreement (NAFTA). This paper uses a global, multisector, computable-general-equilibrium model to provide an analytical assessment of five key provisions in the new agreement, including tighter rules of origin in the automotive, textiles and apparel sectors, more liberalized agricultural trade, and other trade facilitation measures. The results show that together these provisions would adversely affect trade in the automotive, textiles and apparel sectors, while generating modest aggregate gains in terms of welfare, mostly driven by improved goods market access, with a negligible effect on real GDP. The welfare benefits from USMCA would be greatly enhanced with the elimination of U.S. tariffs on steel and aluminum imports from Canada and Mexico and the elimination of the Canadian and Mexican import surtaxes imposed after the U.S. tariffs were put in place.

JEL Classification Numbers: F13, F14, F15
\end{abstract}

Keywords: Economic Integration, Trade Policy, NAFTA, USMCA

Authors’ E-Mail Address: burfisher@gmail.com, flambert@imf.org, and tmatheson@imf.org

\footnotetext{
${ }^{1}$ We would like to thank Cheng Hoon Lim, Edgar Cudmore and various staff of the IMF, Department of Finance Canada, Global Affairs Canada, Agriculture and Agri-Foods Canada, and the Office of the U.S. Trade Representative for useful comments and suggestions on earlier drafts.
} 
CONTENTS

PAGE

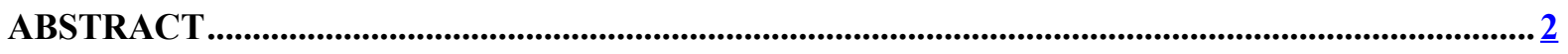

I. INTRODUCTION ......................................................................................................................................

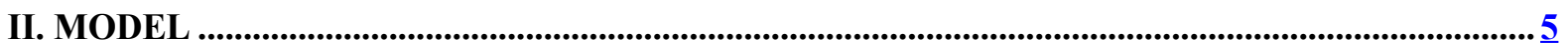

III. DATABASE AGGREGATION ...........................................................................................................

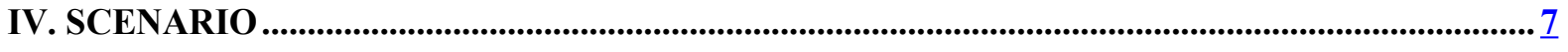

V. RESULTS OF SCENARIO .............................................................................................................. 12

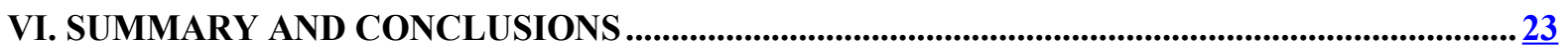

VII. REFERENCES............................................................................................................................... 25

VIII. APPENDIX ............................................................................................................................................................ 28

\section{TABLES}

1. Split of GTAP Motor Vehicle Sector

2. USMCA Model Scenario ___ 11

3. Ad Valorem Equivalents of Non-Tariff Measures ___ 12

4. Effects of USMCA on Welfare ___

5. Effects of USMCA on Real GDP_ 14

6. Effects of USMCA on Real Exchange Rate ___ 16

7. Changes in Aggregate Trade Balances ___

8. Changes in Bilateral Trade Balances due to USMCA ___

9. Effects of USMCA on Real Wages and Rents ___

10. Changes in Bilateral Export Volumes due to USMCA, With and Without Steel and Reciprocal Tariff Reforms __ $\underline{20}$

$\begin{array}{ll}\text { 11. Effect of USMCA on Trade Volume in Vehicles and Parts } & 21 \\ \text { 12. Sectoral Output Effects of USMCA }\end{array}$

12. Sectoral Output Effects of USMCA ___ 22 


\section{INTRODUCTION}

The North-American Free Trade Agreement (NAFTA) between Canada, Mexico, and the United States has been in force since January 1994. When NAFTA negotiations were concluded in 1992, it was the most comprehensive free trade agreement ever negotiated, creating the world's largest market for goods and services. The agreement eliminated almost all tariffs between the three countries and incorporated numerous other innovative provisions. NAFTA influenced other free trade agreements that the United States later negotiated and multilateral negotiations. It also initiated a new generation of trade agreements in the Western Hemisphere and other parts of the world, influencing negotiations in areas such as market access, rules of origin, intellectual property rights, foreign investment, dispute resolution, worker rights, and environmental protection.

NAFTA fundamentally reshaped North American economic relations, driving unprecedented integration between Canada, the United States and Mexico and encouraging a dramatic increase in regional trade and cross-border investment between the three countries. Since the agreement came into effect, trade between the three NAFTA parties has increased from US\$290 billion in 1993 to over US\$ 1.1 trillion in 2017.

Most economists agree that NAFTA has provided benefits to the North American economy by expanding trade and economic linkages between countries, creating more efficient production processes, increasing the availability of lower-priced consumer goods, and improving living standards. However, it has proven difficult to isolate the agreement's beneficial effects from other factors, including rapid technological change, expanded trade with other countries such as China, and unrelated domestic developments in each of the countries. Debate also persists regarding NAFTA's legacy on employment and wages, as some workers and industries have faced painful disruptions amid increased competition while others have gained from new market opportunities. This debate is evidenced in the fact that, after more than a quarter of a century, the impact of NAFTA remains a perennial topic of discussion in the broader debate over the benefits of free trade.

Against this backdrop, the United States launched new trade negotiations with Canada and Mexico soon after President Trump's inauguration in 2017, with the aim of supporting higher-paying jobs and growth. Those culminated in a new trilateral United States - Mexico - Canada trade agreement (USMCA) signed by U.S. President Trump, Canadian Prime Minister Trudeau, and Mexican President Peña Nieto, on November 30, 2018. The agreement still needs to be ratified by the three countries before it can be implemented. It includes tighter rules of origin in the automobile, textile, and apparel sectors, a new labor value content requirement in the auto sector, higher U.S. access to Canadian supply-managed markets, further goods trade facilitation, updated provisions related to financial services, as well as a new currency provision and a provision about entering free trade agreements with non-market economies.

The conclusion of USMCA is occurring in a dynamic trade environment for Canada and Mexico. In March 2018, they joined 9 other countries in the Asia Pacific region in signing the Comprehensive and Progressive Agreement for a Trans-Pacific Partnership (CPTPP). This agreement will provide preferential access by Canada, Mexico, Japan and other CPTPP members to each other's markets. Also, in May 2018, the United States imposed import tariffs of 25 percent on steel and 10 percent on aluminum due to national security concerns, to which U.S. major trade partners (including Canada and Mexico) responded with surtaxes on imports of selected U.S. products. Finally, in April 
and August 2018, the United States levied additional tariffs on a combined US\$ 50 billion of imports from China, which immediately triggered retaliation by China. ${ }^{2}$ The impact of USMCA is analyzed within this context.

This paper uses a global, multisector, computable-general-equilibrium model to provide an analytical assessment of five key provisions of USMCA: (1) higher vehicle and auto parts regional value content requirement, (2) new labor value content requirement for vehicles, (3) stricter rules of origin for USMCA textile and apparel trade, (4) agricultural trade liberalization that increases U.S. access to Canadian supply-managed markets and reduces U.S. barriers on Canadian dairy, sugar and sugar products, and peanuts and peanut products, and (5) trade facilitation measures. In the context of successful ratification of USMCA, the paper also examines the effect of the removal of U.S. tariffs on steel and aluminum imports from Canada and Mexico and their reciprocal withdrawal of surtax countermeasures.

It is worthwhile noting that USMCA is very complex and many aspects of the agreement are not analyzed here due to either modeling limitations (e.g. the review clause and the impact of greater patent protections in the pharmaceutical industry) or significant uncertainty about their qualitative and quantitative effects (e.g. the new chapter on financial services, which essentially codifies what is already practiced in the industry). Likewise, as with all model-based analyses, the results presented here are based on a particular model, set of assumptions and stylized representations of policy details that can be subject to debate. Nevertheless, with these caveats in mind, this paper represents a quantitative analysis of USMCA that can serve as a useful basis of discussion and comparison for future work.

The paper proceeds as follows. Sections II and III describe the analytical framework and the data used in the analyses. Section IV details assumptions underpinning the scenario and section V discusses the results. Section VI concludes with a discussion of the key findings.

\section{MODEL}

This paper uses the GTAP Computable-General-Equilibrium (CGE) model to generate economic impacts. It is a standard, static computable general equilibrium model, documented in detail in Hertel and others (1998) and Corong and others (2017). ${ }^{3}$ Like all models, GTAP has limitations that need to be considered when interpreting the results, such as sensitivities related to calibration choices (see Costinot and Rodriquez-Clare, 2014, for a discussion of some of the pitfalls associated with GCE models).

The model solves for a new, market-clearing equilibrium solution after all prices and quantities adjust following an economic shock. The results describe a medium-term adjustment period, a

\footnotetext{
${ }^{2}$ Subsequently, the United States and China imposed additional tariffs on each other's products. The U.S.-China trade relationship remains fluid.

${ }^{3}$ Extensive details about the model can also be found at: https://www.gtap.agecon.purdue.edu/models/default.asp.
} 
period in which factors are fully mobile within countries but dynamic investment and productivity gains do not yet occur.

The model assumes perfect competition and describes import demand using nested constant elasticity of substitution aggregation functions that define substitutability between domestic goods and imports, and among suppliers of imports. A constant difference of elasticities demand system describes final consumer demand; constant elasticity of transformation functions describe factor mobility among industries; and production functions describe factor substitutability in production technologies. The demand and supply behavior in the model is governed by elasticities of substitution and income that are drawn from the literature and provided in the GTAP database. Import substitution parameter values for textiles/apparel and vehicles/parts are adjusted slightly downward to better reflect the established cross-border supply chains that have developed in these industries and constraints in switching suppliers due to regional content requirements under rules of origin.

The model uses the GTAP v10 database, which describes the world economy in 2014. The database is recalibrated to include ad valorem tariffs from the World Bank's World Integrated Trade Solution (WITS), the ad valorem equivalents of rules of origin, and ad valorem equivalents of non-tariff barriers to services trade drawn from Fontagne and others (2016). The model is then updated in a model experiment to include in the base equilibrium the CPTPP $;{ }^{4}$ U.S. steel and aluminum tariffs; reciprocal surtaxes by Canada, Mexico, China and the European Union (Coalition of American Metal Manufacturers and Users, 2018); and the U.S.-China trade tensions through August 2018 (USTR 2018a and 2018b; China Ministry of Commerce, 2018).

\section{Database Aggregation}

The GTAP v10 database defines 140 regions and 57 commodities, which, for the purposes of this paper, are aggregated into 16 sectors (Appendix Table 1) and 7 regions (Appendix Table 2). Steel and aluminum sectors are aggregated within the "manufacturing nec" sector. This paper also aggregates GTAP's eight factors of production into four: capital, land, unskilled labor and skilled labor.

To facilitate a more detailed analysis of rules of origin provisions, the motor vehicle sector in the GTAP database is split into two sectors, motor vehicles and motor vehicle parts, using the SplitCom utility (Horridge, 2008) (Table 1). Data on production, trade, employment, and tax rates for each split commodity and region in the model are inputs into the utility, which then rebalances the global database to split the motor vehicle sector into vehicles and parts. All other data in the GTAP

\footnotetext{
${ }^{4}$ The CPTPP is assumed to be implemented over the medium-run time frame of the model, and is modeled as the elimination of tariffs among CPTPP members, with the exception of Canadian dairy tariffs (no change of tariff with Mexico, partial reduction of tariffs for other CPTPP members) and Japanese beef tariffs (partial reduction), trade efficiency gains (i.e., reduction of ad valorem tariff equivalent) of 1 percent among CPTPP members, and a reduction of ad valorem tariff equivalents of non-tariff measures in services by 25 percent. Tariffs for textiles and apparel and vehicles and parts are reduced by only one-half to account for the introduction of rules of origin in CPTPP trade.
} 
database are unaffected, and the sum of data for the new variables describing the subdivided sectors is equal to the values of the original sector. ${ }^{5}$

Table 1. Split of GTAP Motor Vehicle Sector

\begin{tabular}{|l|l|l|}
\hline New Sector & HS Code & NAIC Code \\
\hline Motor vehicles & $8701-05$ & 3361 \\
\hline Motor vehicle parts & Parts $8407-8409,8609,8706-8708,8716$ & 3362,3363 \\
\hline
\end{tabular}

\section{SCENARIO}

The CGE model offers a tool for controlled experiments in which the effects of a change in policy or other shock on an economy can be identified and isolated, while holding all other influences constant. The model is used in this analysis to simulate the separate and combined effects of 5 key provisions of USMCA, summarized in Table 2.

\section{1) Vehicle and parts Regional Value Content (RVC) requirements}

USMCA modifies the NAFTA rules of origin (ROOs) to increase the regional value content requirement for vehicles and parts originating in the North American market from 62.5 percent to 75 percent, and to introduce new requirements related to the sourcing of steel, aluminum and core auto parts such as engines and transmissions, while removing NAFTA tracing requirements (USTR, 2018e). Most U.S. and Canadian vehicle production has the capacity to meet the new rules but less than 70 percent of Mexico's vehicle production has the capacity to meet the requirements. The region's trade in vehicle parts is more globally sourced than vehicles, with almost one-quarter of parts traded by Canada and Mexico with the United States already entering outside of NAFTA preferences (Dziczek and others, 2018). Exporters forego preferences when it is more economical to source parts from lower-cost producers outside the region, and instead pay the relatively low mostfavored-nation $(\mathrm{MFN})$ rates on these products.

The efficiency and regulatory costs of compliance with the ROOs in vehicles and parts are represented in this analysis by ad valorem equivalents (AVE) of import tariffs. The compliance costs are approximated in this study to be one-half of the margin of preference (MFN tariff rates minus the preferential NAFTA rates) (Table 3). ${ }^{6}$ This is equivalent to assuming that the added costs of meeting the requirements of the ROOs consume 50 percent of the benefit of the margin of preference. The model scenario approximates the higher content requirements as an increase in the AVE for vehicles from 50 to 75 percent of the preference margin for U.S. and Canadian imports of vehicles and a comparable increase to a 3-percent vehicle tariff by Mexico. North American trade in

\footnotetext{
${ }^{5}$ Data sources used for the split are: World Integrated Trade Solution (WITS); Eurostat; Global Affairs Canada; Government of Canada; Ibisworld; International Organization of Motor Vehicle Manufacturers; Library of the European Parliament; Ministry of Economy, Pro-Mexico; Japan Ministry of Economy, Trade and Industry (MITI); National Bureau of Statistics of China; United States Census Bureau; United States International Trade Administration; and Aguiar (2016).

${ }^{6}$ This is an approximation, drawing on Anson, et al. (2005), who found that average administrative costs amount to about 47 percent of the preference margin in NAFTA.
} 
vehicle parts is assumed to move entirely to MFN tariff rates, which are relatively low, as more of the market shifts abroad in response to higher regional compliance costs. ${ }^{7}$ These stylized representations of the USMCA vehicle and parts provisions capture the conclusion of Schott (2018) on the auto provisions of the USMCA, that the trade agreement "raises rather than lowers barriers to trade and investment ... (and) adds layer upon layer of costly new regulations" to trade in vehicles and parts.

\section{2) Labor Value Content (LVC) requirements for vehicles}

The USMCA introduces a labor value content rule to ROOs that requires 40 percent of a passenger vehicle and 45 percent of a pickup or cargo vehicle to be made by workers who earn a wage of at least US\$16 per hour (USTR, 2018d). Average hourly earnings in Mexico's vehicle sector were US\$3.38 in 2015 (Statista, 2018). Media reports indicate that Mexico expects some production to shift to higher wage member countries, instead of wages fully increasing to required levels. Dziczek and others (2018) concluded that the combination of RVC and LVC rules would cause the costs of trade in vehicles and parts to exceed the benefits of trading under USMCA preferences, so that paying MFN tariffs on imports from Mexico will be the preferred strategy. In the model scenario, labor costs in Mexico's vehicle sector are assumed to increase by 50 percent, representing an increase in the average labor cost to about US\$5 per hour. The increase reflects a conservative assumption that only a portion of exported vehicles will be produced with higher wages in compliance with the LVC requirements. The increase is proxied in the model as an increase in the current labor tax imposed on Mexican vehicle producers. A shortcoming of this approach is that higher labor costs generate tax revenue, rather than directly increasing raising employee wages.

\section{3) Rules that further limit the use of non-USMCA inputs in textile and apparel trade}

While the USMCA provisions on textiles are mostly unchanged from NAFTA, the USMCA tightens the requirements for sewing threads, coated fabrics, and some other textile inputs incorporated into apparel and other finished products to qualify for USMCA trade benefits, and strengthens customs enforcement to prevent fraud and circumventions (USTR, 2018e). The agreement also includes the removal of some restrictive requirements, such as use of originating rayon and visible lining. Tighter regional content requirements will likely affect Mexico and the United States more than Canada, because the low fill rates of Canada's tariff preference levels (TPL) could accommodate an increase in its imports and exports that would not qualify under the new rules (U.S. Customs and Border Protection, 2019; Global Affairs Canada, 2019). TPL's are preferential quotas that allow for apparel made from imported textiles that do not meet the rules of origin (i.e., non-originating goods), but that are subject to significant processing in one or more NAFTA countries to be exported duty-free to other NAFTA countries.

In the model scenario, the tighter content requirements for U.S-Mexico trade in textiles and apparel

\footnotetext{
${ }^{7}$ The assumption that MFN tariffs will be imposed on auto parts may be extreme in the case of Canada because it waives tariffs on imported auto parts used in original equipment manufacturer (OEM) assembly, so Canadian imports of those parts would remain duty free. The single auto parts sector in this model does not distinguish between OEM and other parts. The Armington import demand elasticity in the model captures the imperfect substitutability of North American parts with other sourcing even though ROO compliance costs rise.
} 
are approximated as an increase in the AVE of the rules of origin for these products from 50 to 75 percent of the margin of preference. Even relatively small changes in customs duties and procedures can shift trade from the USMCA to other suppliers. In 2016, 6 percent of NAFTA apparel trade was already under MFN rules because manufacturers found it is not worth the time and resources required to comply with ROOs and documentation (Congressional Research Service, 2017).

\section{4) Agricultural provisions}

The UMCA provides the United States with expanded access of up to 3.6 percent of the domestic Canadian market for dairy, including poultry and egg products (Congressional Research Service, 2018; USTR 2018c). To reciprocate, the United States agreed to provide expanded access for Canadian dairy, sugar, and sugar-containing products, and U.S. tariffs on cotton, peanuts and peanut products imported from Canada will be eliminated after five years.

In the model scenario, the AVE of Canada's dairy tariff-rate quota on U.S. products adjusts to the level required to achieve a target U.S. market penetration equal to about 3 percent of Canada's domestic consumption volume. ${ }^{8}$ The increased access for Canadian dairy products into the U.S.is approximated as a reduction of 50 percent in the AVE of the U.S. dairy import barrier. The model's food products sector includes both sugar, for which Canadian access is increased, and peanuts and their products, for which U.S. tariffs are to be eliminated. These combined provisions are approximated as a 50 percent decline in the U.S. tariff on Canadian food products.

\section{5) Improved goods market access}

One of the most significant updates of NAFTA in the USMCA is the addition of a Customs Administration and Trade Facilitation Chapter. The chapter introduces standardized, modern customs procedures that will improve the efficiency with which goods are shipped across borders in North American trade (USTR, 2018d). The chapter's provisions include single location border inspections, use of IT (electronic submissions of customs forms), greater transparency in customs regulations and procedures, and other practices that will reduce customs inefficiencies and costs (Spak and others, 2018).

The agreement also increases the de minimis import levels for Canada and Mexico, setting higher thresholds for the value of goods shipped by express delivery services that may enter tax and duty free and simplifying their customs treatment. Canada's threshold level is increased from C\$20 to C\$40 for tax-free entry, and C\$150 for duty-free entry with simplified customs forms. Mexico's current $\$ 50$ threshold for tax-free entry is unchanged but is increased to US\$117 for duty-free entry with simplified customs forms. The U.S. threshold, currently $\$ 800$, is unchanged. This provision is expected to be of special benefit to small- and medium-sized companies and on-line retailers because they typically ship in small trade volumes and are more likely to lack the resources to absorb the compliance costs for low-valued shipments (USTR, 2018d and Hufbauer and Jing,

\footnotetext{
${ }^{8}$ The model's dairy sector includes only milk and milk products and eggs. USMCA provides U.S. access of 3.6 percent for dairy, 1.4 percent for eggs, 0.6 percent for chicken and 0.6 percent for turkey.
} 
2018). But the provision also may provide a tax advantage to foreign retailers that domestic retailers do not enjoy.

A number of new measures will facilitate agricultural trade. The agreement provides for a new Canadian grain grading policy that allows U.S.-grown wheat of varieties registered in Canada to receive an official Canadian grain grade so that country of origin statements on quality certificates are no longer required. Other agricultural measures include the modernized SPS chapter, which will support trade in agriculture, fisheries and forestry products through enhanced rules on import checks, audits, equivalence and regionalization. These reinforce and build upon the USMCA members' existing rights and obligations in the original NAFTA and the World Trade Organization SPS Agreement. In addition, the agriculture chapter includes new obligations on science and risk analysis, creates a new mechanism to resolve issues cooperatively and has new provisions to enhance compatibility of SPS measures among the three countries.

In the CGE model, these trade facilitation measures are proxied as a reduction in iceberg trade costs, expressed as AVEs of import tariffs. Hillberry and Zhang (2015) estimate that global adoption of best practices in trade facilitation could yield a reduction of trade costs equal to about 1 percent ad valorem. Most developed countries are already near best practices, so Hillberry and Zhang estimate minimal changes in their efficiency. Trade efficiency gains in Mexico could exceed 1 percent ad valorem. This study makes a conservative assumption that the USMCA reduces trade costs by the ad valorem tariff equivalent of one-tenth of one percent by all partners, with no changes in trade costs for textiles, apparel, dairy, vehicles and parts, which are covered by ROOs. Due to the uncertainty about this assumption, results for aggregate variables are decomposed to show the role of the trade efficiency gain assumption in the model results, and two sensitivity analyses reported in Appendix Tables 5 and 6 . The sensitivity experiments describe the welfare and GDP effects of the USMCA with a higher, one-half percent ad valorem equivalent value of the trade facilitation provisions by all partners, and with higher trade efficiency gains in Mexico that range between 0.5 percent and 2.0 percent AVE while U.S. and Canadian efficiency gains remain at 0.1 percent AVE.

In addition to the five key provisions of the USMCA, the scenario is extended to explore the potential removal of U.S. steel and aluminum tariffs on Canada and Mexico, and the elimination of their reciprocal surtaxes on imports from the United States. The extension is included because Canada and Mexico could require the United States to lift its tariffs on their steel and aluminum products as a condition for ratifying the USMCA. The U.S., Canadian and Mexican steel and aluminum tariffs and surtaxes are already incorporated in the model's base equilibrium. The extended USMCA model scenario removes them. 


\begin{tabular}{|c|c|}
\hline \multicolumn{2}{|c|}{ Table 2. USMCA Model Scenario } \\
\hline \multirow[t]{5}{*}{ USMCA } & $\begin{array}{l}\text { Vehicles and Parts RVC requirements. The increase in } \\
\text { the regional value content in USMCA vehicle trade is } \\
\text { described as an increase in the AVE of ROOs on U.S. } \\
\text { and Canada vehicle imports from } 50 \text { to } 75 \text { percent of the } \\
\text { margin of preference, and a } 3 \text { percent tariff on Mexican } \\
\text { vehicle imports. RVC requirements for parts described } \\
\text { as the imposition of MFN tariff rates. }\end{array}$ \\
\hline & $\begin{array}{l}\text { Vehicle LVC requirements. } \$ 16 / \text { hour minimum wage } \\
\text { requirement is described as a } 50 \% \text { increase in labor costs } \\
\text { in Mexico's vehicle production. }\end{array}$ \\
\hline & $\begin{array}{l}\text { Textiles and Apparel. Stricter rules of origin and } \\
\text { strengthened customs enforcement in textiles and apparel } \\
\text { described as an increase in the AVE of ROOs in U.S.- } \\
\text { Mexico trade from } 50 \text { to } 75 \text { percent of the margin of } \\
\text { preference in these sectors. Due to low fill rates of its } \\
\text { TPLs, no change is made to Canadian barriers to textiles } \\
\text { and apparel trade with USMCA partners. }\end{array}$ \\
\hline & $\begin{array}{l}\text { Dairy, Sugar and Peanuts. Expanded U.S. access to } \\
\text { Canada for dairy described as a reduction in the AVE of } \\
\text { Canada's tariff rate quota on U.S. dairy products that } \\
\text { causes U.S. exports to equal to about } 3 \text { percent of } \\
\text { Canada's domestic market volume, with a reciprocal } \\
\text { fifty-percent reduction of U.S. tariffs on Canadian dairy } \\
\text { and food manufactures (includes sugar, peanuts and } \\
\text { products). }\end{array}$ \\
\hline & $\begin{array}{l}\text { Customs and Trade Facilitation. Improved goods } \\
\text { market access described as a one-tenth of a percent } \\
\text { reduction in regional merchandise trade costs, excluding } \\
\text { products subject to ROOs. }\end{array}$ \\
\hline \multirow[t]{2}{*}{$\begin{array}{l}\text { Extension: Reform of U.S. Steel } \\
\text { and Aluminum Tariffs and } \\
\text { Reciprocal Surtaxes }\end{array}$} & $\begin{array}{l}\text { U.S. Steel and Aluminum Tariffs. U.S. tariffs on steel } \\
\text { and aluminum imports from Canada and Mexico are } \\
\text { eliminated. }\end{array}$ \\
\hline & $\begin{array}{l}\text { Reciprocal Surtaxes. Canada and Mexico reciprocal } \\
\text { surtaxes on imports from the United States are } \\
\text { eliminated. }\end{array}$ \\
\hline
\end{tabular}




\begin{tabular}{|l|c|c|c|c|c|c|}
\hline \multicolumn{7}{|c|}{ Table 3. Ad Valorem Equivalents of Non-Tariff Measures } \\
\hline & $\begin{array}{c}\text { Imports } \\
\text { from U.S. }\end{array}$ & $\begin{array}{c}\text { Imports } \\
\text { from } \\
\text { Mexico }\end{array}$ & $\begin{array}{c}\text { Imports } \\
\text { from } \\
\text { Canada }\end{array}$ & $\begin{array}{c}\text { Imports } \\
\text { from U.S. }\end{array}$ & $\begin{array}{c}\text { Imports } \\
\text { from } \\
\text { Canada }\end{array}$ & $\begin{array}{c}\text { Imports } \\
\text { from } \\
\text { Mexico }\end{array}$ \\
\hline Textile & 3.1 & 6.6 & 5.0 & 5.1 & 3.3 & 4.6 \\
\hline Apparel & 7.8 & 8.2 & 10.0 & 10.0 & 6.3 & 5.3 \\
\hline Motor vehicles & 2.9 & 3.0 & 17.0 & 15.4 & 1.5 & 5.3 \\
\hline Motor vehicles parts & 1.3 & 1.1 & 0.5 & 4.0 & 0.7 & 0.6 \\
\hline Finance/insurance & 67.4 & 50.7 & 63.5 & 84.6 & 52.6 & 52.6 \\
\hline Other services & 69.9 & 52.4 & 72.4 & 115.2 & 63.3 & 63.3 \\
\hline $\begin{array}{l}\text { Sources: AVEs of rules of origin in textiles, apparel, motor vehicles and parts calculated as 50\% of the margin of } \\
\text { preference (MFN tariff rates from WITS minus applied tariff rates from GTAP v10 database). AVEs of NTMs in } \\
\text { finance, insurance and other services drawn from Fontagne and others (2016). }\end{array}$ \\
\hline
\end{tabular}

\section{RESUlts OF SCENARIO}

\section{Macroeconomic Effects}

In total, USMCA countries have a combined welfare gain of $\$ 538$ million (Table 4). ${ }^{9}$ Canada's welfare increases by $\$ 700$ million and Mexico's increases by $\$ 600$ million, while that of the United States declines. The effects on members' real GDP is negligible (Table 5).

Tightening the rules of origin in vehicles and parts by increasing the RVC and introducing LVC rules contributes a US\$700 million welfare loss to the region. Canada benefits from the RVC through terms of trade gains as the decline in its vehicle export supply boosts its export price, and its competitive position relative to Mexico improves (although both see declining sales to the United States); but it loses from the LVC, which increases the prices of its vehicle imports. Mexico experiences a welfare gain from the LVC, due mainly to the increase in the price of its reduced export supply of vehicles. The United States experiences a welfare loss from both the RVC and the LVC because these measures increase the prices of its vehicle and parts imports from Canada and Mexico. Tightening the rules of origin and customs enforcement for textiles and apparel creates inefficiencies that imply a total regional welfare loss of US\$164 million, with negative welfare impacts for Mexico and the United States, but not for Canada due its excess capacity under its TPLs.

The US\$56 million gain in the region's welfare due to the agricultural provisions of USMCA includes a welfare loss to the United States (-US\$85 million), stemming from very small terms of trade losses across a range of products. Canada's $\$ 139$ million welfare gain from the agricultural provisions results mostly from higher U.S. demand for its dairy and processed food exports.

Trade facilitation has the most potential to provide gains from the agreement, contributing $\$ 1.3$ billion to the region's total welfare gain in the USMCA scenario. These potential gains offset the

\footnotetext{
${ }^{9}$ Welfare gains are measured in terms of consumption equivalent variation. This measure compares pre- and postreform consumption quantities, with both valued in base year prices.
} 
region's welfare losses that follow the agreement's added restrictions on regional trade in vehicle and parts, and textile and apparel.

If ratification of USMCA extends to include an elimination of U.S. steel and aluminum tariffs and the reciprocal surtaxes imposed by Canada and Mexico, the region as a whole has a welfare gain of nearly $\$ 2.5$ billion, mostly benefitting the United States and boosting total USMCA welfare gains to $\$ 3$ billion. Removing U.S. steel and aluminum tariffs will yield a welfare gain for Canada of \$1.4 billion and for Mexico of $\$ 600$ million, but results in a $\$ 1.6$ billion loss to the United States, which had benefited from the declining prices of its imports when its tariffs reduced U.S. import demand. Removing reciprocal import surtaxes causes the same terms of trade losses to Canada and Mexico as the removal of U.S. import tariffs generated for the United States. The elimination of reciprocal surtaxes causes a welfare loss for Canada of $\$ 900$ million and for Mexico of $\$ 600$ million as their increased demand for imports from the United States causes import prices to rise. Conversely, there is a welfare gain to the United States of $\$ 2.1$ billion from removing these taxes. The steel tariff and tax reforms support a minimal real GDP gain in Canada (0.02 percent) while effects on the GDP's of Mexico and the United States are about zero. 


\begin{tabular}{|l|r|r|r|r|r|r|r|r|r|}
\hline \multicolumn{7}{|c|}{ Table 4. Effects of USMCA on Welfare, with and without Reforms of U.S. Steel and Aluminum Tariffs and Reciprocal Surtaxes } \\
Reciprocal(\$US millions) \\
\hline
\end{tabular}

\begin{tabular}{|c|c|c|c|c|c|c|c|c|c|c|}
\hline & \multicolumn{6}{|c|}{ USMCA } & \multicolumn{3}{|c|}{ Steel/surtax reforms } & \multirow{3}{*}{$\begin{array}{c}\text { Total } \\
\text { USMCA }+ \text { steel and surtax reforms }\end{array}$} \\
\hline & $\begin{array}{l}\text { Veh } \\
\text { and }\end{array}$ & $\begin{array}{l}\text { cles } \\
\text { parts }\end{array}$ & $\begin{array}{l}\text { Textile } \\
\text { and }\end{array}$ & Agriculture & $\begin{array}{c}\text { Trade } \\
\text { facilitation }\end{array}$ & $\begin{array}{c}\text { Total } \\
\text { USMCA }\end{array}$ & $\begin{array}{l}\text { Remove } \\
\text { U.S. steel }\end{array}$ & $\begin{array}{l}\text { Remove } \\
\text { reciprocal }\end{array}$ & $\begin{array}{l}\text { Total } \\
\text { tariff }\end{array}$ & \\
\hline & $\mathrm{RVC}$ & LVC & $\begin{array}{l}\text { apparel } \\
\text { ROOs }\end{array}$ & & & & $\begin{array}{l}\text { and } \\
\text { aluminum } \\
\text { tariffs }\end{array}$ & surtaxes & $\begin{array}{c}\text { and } \\
\text { surtax } \\
\text { reforms }\end{array}$ & \\
\hline Canada & 0.00 & 0.00 & 0.00 & 0.00 & 0.02 & 0.02 & 0.02 & 0.00 & 0.02 & 0.04 \\
\hline USA & 0.00 & 0.00 & 0.00 & 0.00 & 0.00 & 0.00 & 0.00 & 0.00 & 0.00 & 0.00 \\
\hline Mexico & 0.01 & 0.01 & 0.00 & 0.00 & 0.01 & -0.01 & 0.00 & 0.01 & 0.00 & 0.00 \\
\hline
\end{tabular}




\section{Competitiveness and Trade}

In the GTAP model, the real exchange rate measures the price index of a country's factors of production (labor, capital and land) relative to the global average. Trade agreements result in global changes in real exchange rates (Table 6) that influence the export competitiveness of member countries and their purchasing power over imports. USMCA causes a small appreciation of the Canadian real exchange rate relative to its partners, no change in the U.S. exchange rate and a small depreciation of the Mexican exchange rate relative to both partners. The extension of the agreement to include elimination of steel and aluminum tariffs and reciprocal surtaxes causes real appreciation of the Canadian and U.S. exchange rates and a moderation of Mexico's real depreciation.

All three countries have initial aggregate trade deficits (exports minus imports) and these are not substantially impacted by the trade agreement (Table 7). USMCA causes trade deficits to widen slightly in Canada (\$36 million) and the United States (\$275 million) but that of Mexico improves modestly. Extending the agreement to include reform of steel and aluminum tariffs and reciprocal surtaxes will further widen the Canadian and U.S. deficits while that of Mexico will continue to narrow.

The value of trade among the three countries will decrease by $\$ 4.4$ billion ( 0.4 percent) due to USMCA, from an initial value of trade of \$1.13 billion (Table 8). Both Canada and Mexico have initial trade surpluses with the United States in the model's baseline; these will widen with USMCA, due mostly to the reduction in trade with the United States in vehicles and parts. Extending the agreement to include steel and aluminum tariffs and the surtax reforms will boost trade among the partners by about $\$ 15$ billion relative to the baseline and narrow the surpluses of Canada and Mexico with the United States. 


\begin{tabular}{|l|}
\hline \multicolumn{10}{|c|}{ Table 6. Effects of USMCA on Real Exchange Rate, with and without Reforms of U.S. Steel and Aluminum Tariffs } \\
and Reciprocal Surtaxes(percent change from base) \\
\hline
\end{tabular}


Table 7. Changes in Aggregate Trade Balances Due to USMCA, with and without Reforms of Steel and Aluminum Tariffs and Reciprocal Surtaxes (\$US million)

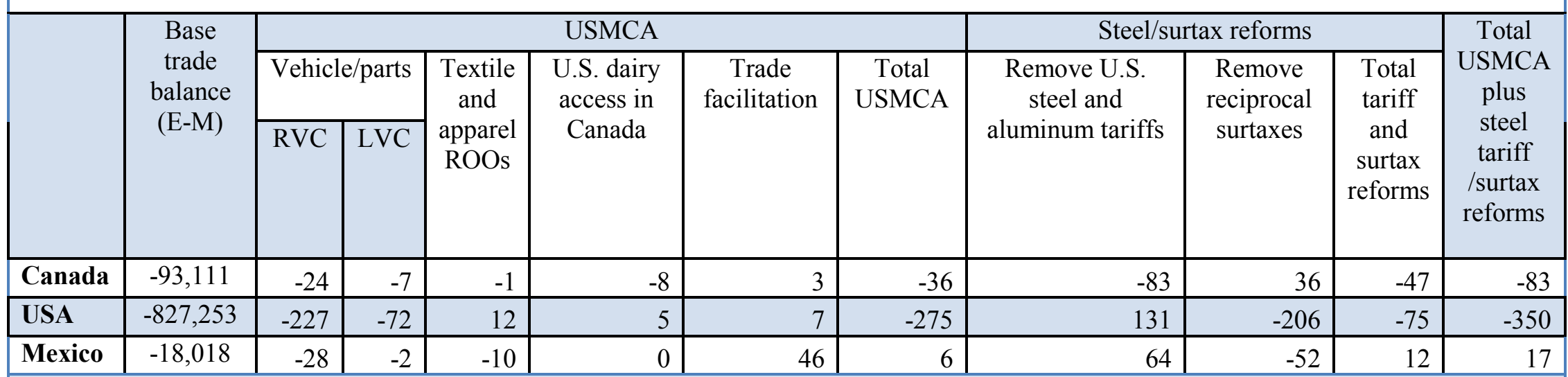

Notes: Exports valued in $f o b$ prices; imports valued in cif prices. A negative trade balance indicates a trade deficit, and a negative impact denotes an increase in a trade deficit.

Source: Base values are from GTAP v10 database with 2014 base year, updated to reflect the effect of the CPTPP, U.S. steel and aluminum tariffs, reciprocal surtaxes by Canada, Mexico, China and the European Union, and the U.S.-China trade tensions through August 2018. 


\begin{tabular}{|c|c|c|c|c|c|c|c|c|c|c|}
\hline \multicolumn{11}{|c|}{$\begin{array}{c}\text { Table 8. Changes in Bilateral Trade Balances due to USMCA, with and without Reforms of U.S. Steel and Aluminum } \\
\text { Tariffs and Reciprocal Surtaxes (SUS million) }\end{array}$} \\
\hline & \multirow{2}{*}{$\begin{array}{l}\text { Total intra- } \\
\text { North } \\
\text { American } \\
\text { trade }\end{array}$} & \multicolumn{3}{|c|}{ Canada } & \multicolumn{3}{|c|}{ Mexico } & \multicolumn{3}{|c|}{ US } \\
\hline & & with Mexico & with U.S. & $\begin{array}{l}\text { with } \\
\text { ROW }\end{array}$ & $\begin{array}{l}\text { with } \\
\text { Canada }\end{array}$ & with U.S. & $\begin{array}{l}\text { with } \\
\text { ROW }\end{array}$ & $\begin{array}{c}\text { with } \\
\text { Canada }\end{array}$ & $\begin{array}{l}\text { with } \\
\text { Mexico }\end{array}$ & $\begin{array}{l}\text { with } \\
\text { ROW }\end{array}$ \\
\hline \multicolumn{11}{|c|}{ Base values } \\
\hline Exports & $1,129,391$ & 10,461 & 305,448 & 157,541 & 29,631 & 303,820 & 88,508 & 271,368 & 208,664 & $1,211,670$ \\
\hline Imports & & 29,903 & 275,144 & 268,030 & 10,582 & 211,907 & 218,119 & 312,689 & 308,025 & $1,930,777$ \\
\hline Balance (X-M) & & $-19,442$ & 30,304 & $-110,489$ & 19,049 & 91,913 & $-129,611$ & $-41,321$ & $-99,361$ & $-719,107$ \\
\hline \multicolumn{11}{|c|}{ USMCA scenario } \\
\hline Exports & $1,124,986$ & 10,452 & 305,387 & 157,260 & 29,660 & 302,130 & 88,729 & 271,066 & 206,291 & $1,212,634$ \\
\hline Imports & & 29,932 & 274,848 & 267,983 & 10,573 & 209,511 & 219,079 & 312,631 & 306,354 & $1,931,073$ \\
\hline Balance (X-M) & & $-19,480$ & 30,539 & $-110,723$ & 19,087 & 92,619 & $-130,350$ & $-41,565$ & $-100,063$ & $-718,439$ \\
\hline Change in balance & & -38 & 235 & -234 & 38 & 706 & -739 & -244 & -702 & 668 \\
\hline \multicolumn{11}{|c|}{ USMCA scenario plus reforms of U.S. steel and aluminum tariffs and reciprocal surtaxes } \\
\hline Exports & $1,144,317$ & 10,279 & 310,356 & 156,838 & 29,525 & 305,299 & 88,604 & 278,095 & 210,763 & $1,208,349$ \\
\hline Imports & & 29,796 & 281,983 & 265,402 & 10,398 & 214,054 & 217,608 & 317,635 & 309,548 & $1,930,154$ \\
\hline Balance (X-M) & & $-19,517$ & 28,373 & $-108,564$ & 19,127 & 91,245 & $-129,004$ & $-39,540$ & $-98,785$ & $-721,805$ \\
\hline Change in balance & & -75 & $-1,931$ & 1,925 & 78 & -668 & 607 & 1,781 & 576 & $-2,698$ \\
\hline \multicolumn{11}{|c|}{$\begin{array}{l}\text { Notes: Exports valued in fob prices; imports valued in cif prices. Sum of regions' exports to partners do not equal their global exports because exports to global } \\
\text { transport sector are not reported here. A positive trade balance indicates a trade surplus, and a positive change in a balance denotes an increase in a trade } \\
\text { surplus, or reduction of a deficit. } \\
\text { Source: Base values are from GTAP v10 database with } 2014 \text { base year, updated to reflect the effect of the CPTPP, U.S. steel and aluminum tariffs, reciprocal } \\
\text { surtaxes by Canada, Mexico, China and the European Union, and the U.S.-China trade tensions through August } 2018 \text {. }\end{array}$} \\
\hline
\end{tabular}


Wages for unskilled and skilled labor are unchanged in Canada and the United States due to USMCA but decline in Mexico (Table 9). The RVC puts the greatest downward pressure on wages but the LVC, too, contributes to lower wages as higher labor costs in Mexico's vehicle production reduce demand for workers in both vehicle and parts production. Extending the agreement to include removal of steel and aluminum tariffs and reciprocal surtaxes moderates this wage loss by supporting an increase in Mexican production and exports of machinery and manufactures, which are relatively labor-intensive industries.

\begin{tabular}{|c|c|c|c|}
\hline & Canada & Mexico & United States \\
\hline & \multicolumn{3}{|c|}{ USMCA without tariff and surtax reforms } \\
\hline Land & -0.1 & 0.8 & 0.0 \\
\hline $\begin{array}{l}\text { Unskilled } \\
\text { labor }\end{array}$ & 0.0 & -0.4 & 0.0 \\
\hline Skilled labor & 0.0 & -0.2 & 0.0 \\
\hline \multirow[t]{2}{*}{ Capital } & 0.0 & -0.1 & 0.0 \\
\hline & \multicolumn{3}{|c|}{ USMCA with tariff and surtax reforms } \\
\hline Land & -1.0 & -0.2 & 0.1 \\
\hline $\begin{array}{l}\text { Unskilled } \\
\text { labor }\end{array}$ & 0.2 & -0.2 & 0.0 \\
\hline Skilled labor & 0.2 & 0.0 & 0.0 \\
\hline Capital & 0.2 & 0.1 & 0.0 \\
\hline
\end{tabular}

\section{Sectoral Effects}

USMCA will lead to a reduction in trade volumes among the partners, driven by a decline in vehicle and parts trade, despite the boost in U.S.- Canada trade in dairy products and food items. Extension of the agreement to include steel and retaliatory tariff reforms leads to some shifts away from trade between Mexico and Canada, which is relatively limited, toward their increased trade with the United States. Most of the gains in trade volumes in an extended agreement occur in U.S. imports of manufactures, which includes steel and aluminum, with broad gains in U.S. exports across the wide range of products targeted by the reciprocal surtaxes. 


\begin{tabular}{|c|c|c|c|c|c|c|c|c|c|c|c|c|}
\hline & \multicolumn{4}{|c|}{ Canada exports to: } & \multicolumn{4}{|c|}{ Mexico to: } & \multicolumn{4}{|c|}{ United States to: } \\
\hline & \multicolumn{2}{|c|}{ Mexico } & \multicolumn{2}{|c|}{ United States } & \multicolumn{2}{|c|}{ Canada } & \multicolumn{2}{|c|}{ United States } & \multicolumn{2}{|c|}{ Canada } & \multicolumn{2}{|c|}{ Mexico } \\
\hline & USMCA & $\begin{array}{c}\text { USMCA } \\
+ \text { steel } \\
\text { tariff } \\
\text { /surtax } \\
\text { reforms } \\
\end{array}$ & USMCA & $\begin{array}{c}\text { USMCA } \\
+ \text { steel } \\
\text { tariff } \\
\text { /surtax } \\
\text { reforms }\end{array}$ & USMCA & $\begin{array}{c}\text { USMCA } \\
+ \text { steel } \\
\text { tariff } \\
\text { /surtax } \\
\text { reforms }\end{array}$ & USMCA & $\begin{array}{c}\text { USMCA } \\
+ \text { steel } \\
\text { tariff } \\
\text { /surtax } \\
\text { reforms }\end{array}$ & USMCA & $\begin{array}{l}\text { USMCA + } \\
\text { steel tariff } \\
\text { /surtax } \\
\text { reforms }\end{array}$ & USMCA & $\begin{array}{c}\text { USMCA + } \\
\text { steel tariff } \\
\text { /surtax } \\
\text { reforms }\end{array}$ \\
\hline Crops & -0.1 & -2.6 & 0.0 & 0.1 & 0.6 & 0.9 & 0.5 & 1.0 & 0.3 & -0.1 & 0.1 & 1.3 \\
\hline Livestock & -0.6 & -0.8 & -0.1 & 0.0 & 1.1 & 1.7 & 0.8 & 1.7 & 0.6 & 0.1 & -0.3 & -0.8 \\
\hline Dairy & -0.9 & -14.4 & 16.4 & 16.0 & -1.7 & -2.0 & 0.8 & 0.5 & 10.0 & 10.0 & -0.5 & 25.5 \\
\hline Food mfg. & -0.3 & -5.8 & 2.5 & 2.5 & 1.2 & -2.0 & 0.8 & 0.9 & 0.4 & 6.1 & 0.0 & 9.2 \\
\hline Resources & -0.2 & -0.3 & 0.0 & -0.6 & 1.1 & 1.1 & 1.1 & 0.6 & 0.3 & 0.6 & 0.1 & 0.3 \\
\hline Textiles & 5.2 & 5.1 & 0.2 & -0.2 & 0.0 & -0.5 & -14.7 & -15.3 & 0.1 & -0.1 & -11.9 & -12.0 \\
\hline Apparel & 2.2 & 1.9 & 0.2 & -0.2 & -1.2 & -2.0 & -17.5 & -18.2 & 0.2 & -0.2 & -26.2 & -26.4 \\
\hline Lumber & -0.3 & -1.2 & 0.1 & -0.3 & 1.8 & -1.0 & 1.8 & 1.3 & 0.5 & 5.8 & 0.1 & 3.7 \\
\hline Paper/publ. & -0.2 & -0.6 & 0.1 & -0.3 & 1.2 & 0.8 & 1.2 & 0.8 & 0.4 & 0.3 & 0.1 & 0.0 \\
\hline Petr. \& prods. & -0.3 & -0.4 & 0.2 & 0.0 & 1.2 & -0.5 & 1.4 & 0.9 & 0.3 & 1.8 & 0.0 & -0.1 \\
\hline Motor vehicles & -5.7 & -5.7 & -1.7 & -1.6 & -4.0 & -3.9 & -9.6 & -9.5 & -1.8 & -1.8 & -11.8 & -11.9 \\
\hline Vehicle parts & 2.6 & 3.2 & -1.9 & -1.5 & -2.3 & -2.1 & -3.2 & -3.2 & -1.7 & -1.6 & -6.5 & -6.5 \\
\hline Electr. equip. & 0.8 & 0.0 & 0.4 & -0.4 & 1.5 & 1.5 & 1.7 & 1.6 & 0.5 & 0.1 & 1.1 & 0.7 \\
\hline Mach. nec. & 0.0 & 1.0 & 0.1 & 0.9 & 1.6 & 1.7 & 1.8 & 2.9 & 0.3 & 1.4 & 0.4 & 0.2 \\
\hline MFG nec & -0.2 & -4.2 & 0.0 & 19.7 & 0.6 & -2.6 & 0.6 & 11.2 & 0.1 & 20.6 & -0.1 & 17.8 \\
\hline Finance/ins. & -0.6 & -1.1 & -0.2 & -0.9 & 0.9 & 0.7 & 0.7 & 0.3 & 0.2 & 0.2 & -0.3 & -0.3 \\
\hline Other services & -0.6 & -1.1 & -0.3 & -1.0 & 1.1 & 0.8 & 1.0 & 0.4 & 0.2 & 0.1 & -0.3 & -0.4 \\
\hline $\begin{array}{l}\text { Trade- weighted } \\
\text { avg. chg. }\end{array}$ & -0.2 & -1.8 & -0.1 & 1.5 & -0.2 & -0.6 & -0.7 & 0.4 & -0.1 & 2.4 & -1.1 & 1.0 \\
\hline
\end{tabular}


The RVC and LVC provisions lead to a decline in intra-USMCA trade in vehicles and a more globalized sourcing of both vehicles and vehicle parts from non-USMCA producers (Table 11). The higher costs of production in USMCA region lead to an increase in consumer prices and a decline in consumer demand for vehicles in all three countries.

\begin{tabular}{|c|c|c|c|c|c|c|c|}
\hline \multicolumn{8}{|c|}{$\begin{array}{l}\text { Table 11. Effect of USMCA on Trade Volume in Vehicles and Parts } \\
\text { (percent change from base) }\end{array}$} \\
\hline & & & & nporters & & & \\
\hline \multirow[t]{2}{*}{ Exporters } & Canada & USA & Mexico & China & $\begin{array}{l}\text { Other } \\
\text { Asia }\end{array}$ & EU_27 & ROW \\
\hline & \multicolumn{7}{|c|}{ Motor Vehicles } \\
\hline Canada & - & -1.7 & -5.7 & -1.3 & -1.3 & -1.3 & -1.3 \\
\hline USA & -1.8 & - & -11.8 & -0.1 & -0.1 & -0.1 & -0.1 \\
\hline Mexico & -4.0 & -9.6 & - & -4.3 & -4.2 & -4.3 & -4.3 \\
\hline China & 2.6 & 1.9 & 7.2 & - & 0.1 & 0.1 & 0.1 \\
\hline Other Asia & 2.6 & 1.9 & 7.2 & 0.1 & 0.0 & 0.0 & 0.1 \\
\hline EU_27 & 2.6 & 1.9 & 7.2 & 0.1 & 0.1 & 0.1 & 0.1 \\
\hline \multirow[t]{2}{*}{ ROW } & 2.6 & 1.9 & 7.2 & 0.1 & 0.1 & 0.1 & 0.1 \\
\hline & \multicolumn{7}{|c|}{ Motor Vehicle Parts } \\
\hline Canada & - & -1.9 & 2.6 & -1.2 & -1.1 & -1.1 & -1.2 \\
\hline USA & -1.7 & - & -6.5 & 0.0 & 0.2 & 0.1 & 0.0 \\
\hline Mexico & -2.3 & -3.2 & - & -2.6 & -2.5 & -2.5 & -2.6 \\
\hline China & 2.2 & 1.5 & 4.8 & - & 0.3 & 0.2 & 0.1 \\
\hline Other Asia & 2.2 & 1.5 & 4.8 & 0.1 & 0.2 & 0.2 & 0.1 \\
\hline EU_27 & 2.2 & 1.5 & 4.8 & 0.1 & 0.2 & 0.2 & 0.1 \\
\hline ROW & 2.2 & 1.5 & 4.9 & 0.1 & 0.3 & 0.2 & 0.1 \\
\hline
\end{tabular}

The change in trade flows due to USMCA lead to structural changes in the composition of production in Canada, Mexico and the United States (Table 12). In Canada, the largest output effects of the modelled USMCA provisions, in percentage change terms, will be the contraction of its motor vehicles sector, accompanied by a decline in parts production. In Mexico, the contraction in vehicle output will exceed 5 percent, while the vehicle parts, textile and apparel sectors will also contract. Mexico's output gains in electrical equipment, machinery and other manufacturing will help to offset those losses. In the United States, the most notable declines occur in the textiles and vehicle parts sectors, with vehicle production also contracting due in part to the negative effect of higher prices on consumer demand. Extending USMCA to include tariff reforms has diverse sectoral implications because of the broad targeting of the reciprocal tariffs across U.S. industries. 


\begin{tabular}{|c|c|c|c|c|c|c|c|c|c|}
\hline & \multicolumn{3}{|c|}{ Canada } & \multicolumn{3}{|c|}{ Mexico } & \multicolumn{3}{|c|}{ United States } \\
\hline & \begin{tabular}{|l|} 
Base \\
value of \\
output \\
(\$US \\
mill.) \\
\end{tabular} & $\begin{array}{l}\text { USMCA } \\
\text { ( } \% \\
\text { chng.) }\end{array}$ & $\begin{array}{l}\text { USMCA } \\
+ \text { steel tariff } \\
/ \text { surtax } \\
\text { reforms } \\
(\% \text { chng. })\end{array}$ & $\begin{array}{l}\text { Base } \\
\text { value of } \\
\text { output } \\
\text { (\$US } \\
\text { mill.) }\end{array}$ & $\begin{array}{l}\text { USMCA } \\
(\% \\
\text { chng.) }\end{array}$ & $\begin{array}{l}\text { USMCA } \\
+ \text { steel tariff } \\
/ \text { surtax } \\
\text { reforms } \\
(\% \text { chng. })\end{array}$ & $\begin{array}{l}\text { Base value } \\
\text { of output } \\
\text { (\$US } \\
\text { mill.) }\end{array}$ & $\begin{array}{l}\text { USMCA } \\
(\% \\
\text { chng.) }\end{array}$ & $\begin{array}{l}\text { USMCA } \\
+ \text { steel tariff } \\
/ \text { surtax } \\
\text { reforms } \\
(\% \text { chng. })\end{array}$ \\
\hline Crops & 34,117 & -0.05 & -0.30 & 31,329 & 0.23 & 0.00 & 205,522 & 0.00 & 0.00 \\
\hline Livestock & 18,194 & 0.16 & -0.10 & 17,272 & 0.14 & -0.20 & 142,845 & 0.00 & 0.20 \\
\hline Dairy & 16,319 & 0.05 & 0.00 & 21,169 & 0.13 & -1.10 & 118,726 & 0.02 & 0.30 \\
\hline Food mfg. & 104,319 & 0.46 & -0.20 & 146,871 & 0.17 & -0.30 & 909,287 & -0.01 & 0.20 \\
\hline Resources & 192,801 & -0.08 & -0.30 & 132,952 & 0.64 & 0.40 & 427,261 & 0.00 & 0.00 \\
\hline Textiles & 5,100 & 0.14 & 0.00 & 8,751 & -2.16 & -2.40 & 200,680 & -0.23 & -0.30 \\
\hline Apparel & 3,098 & 0.00 & -0.20 & 14,833 & -4.46 & -4.80 & 133,293 & 0.02 & -0.10 \\
\hline Lumber & 29,025 & -0.04 & -0.40 & 6,872 & 0.32 & 0.40 & 360,194 & 0.00 & 0.00 \\
\hline Paper/publ. & 53,434 & -0.04 & -0.30 & 19,801 & 0.28 & 0.10 & 589,234 & 0.01 & 0.00 \\
\hline $\begin{array}{l}\text { Petr. \& } \\
\text { prods. }\end{array}$ & 219,040 & -0.05 & -0.40 & 181,900 & 0.34 & 0.10 & $2,143,790$ & 0.02 & 0.00 \\
\hline $\begin{array}{l}\text { Motor } \\
\text { vehicles }\end{array}$ & 61,438 & -1.29 & -1.20 & 63,192 & -5.63 & -5.60 & 449,108 & -0.03 & 0.00 \\
\hline Vehicle parts & 28,364 & -0.93 & -0.50 & 75,911 & -2.11 & -2.10 & 283,042 & -0.44 & -0.50 \\
\hline Electr. equip. & 19,173 & 0.02 & -0.60 & 77,835 & 1.45 & 1.40 & 710,607 & 0.05 & -0.20 \\
\hline Mach. nec. & 90,632 & -0.17 & 0.20 & 98,638 & 1.41 & 2.30 & $1,578,879$ & 0.01 & -0.10 \\
\hline MFG nec & 125,363 & -0.11 & 3.90 & 113,575 & 0.27 & 1.90 & $1,063,529$ & -0.02 & 0.50 \\
\hline Finance/ins. & 211,696 & 0.01 & -0.10 & 59,442 & 0.14 & 0.00 & $2,673,975$ & 0.00 & 0.00 \\
\hline $\begin{array}{l}\text { Other } \\
\text { services }\end{array}$ & $2,191,349$ & 0.02 & 0.00 & $1,227,024$ & 0.03 & 0.00 & $19,923,556$ & 0.00 & 0.00 \\
\hline
\end{tabular}




\section{Summary AND CONCLUSIONS}

Using a global, multisector, computable-general-equilibrium model, this paper provides an analytical assessment of the potential effects of five key provisions of USMCA. USMCA is explored within the context of the simultaneous implementation of the CPTPP, the U.S. imposition of tariffs on steel and aluminum imports and retaliation by Canada, Mexico, China and the European Union, and the U.S.-China trade tensions. The analysis also considers the extension of USMCA to include removal of U.S. tariffs on Canadian and Mexican steel and aluminum imports and of the Canadian and Mexican reciprocal surtaxes. The sensitivity analyses examine the effect of alternative rates of trade efficiency gains due to USMCA's new provisions on customs facilitation.

At the aggregate level, effects of the USMCA are relatively small. According to the analysis of this paper, key provisions in USMCA would lead to diminished economic integration in North America, reducing trade among the three North American partners by more than US $\$ 4$ billion (0.4 percent) while offering members a combined welfare gain of US\$538 million. Effects of the USMCA on real GDP are negligible. Most of the benefits of USMCA would come from trade facilitation measures that modernize and integrate customs procedures to further reduce trade costs and border inefficiencies. Changes in trade flows due to USMCA would also lead to structural changes in the composition of production across North America. Depending on each country's circumstances, some sectors benefit from greater trade integration while others experience declines in output and job losses. Changes in industrial structure that result from changing trade flows prompt employees to move from contracting to expanding sectors. In the aggregate, real wages for skilled and unskilled workers in Mexico decline slightly due to the new provisions of USMCA, but wages are unaffected in Canada and the United States.

The results show that the tighter rules of origin in the auto sector and the labor value content requirement would not achieve their desired outcomes. The new rules lead to a decline in the production of vehicles and parts in all three North-American countries, with shifts toward greater sourcing of both vehicles and parts from outside of the region. Consumers would face higher vehicle prices and respond with lower demanded quantities. Higher labor costs in Mexico's vehicle sector would lead to greater-capital intensity as Mexico's producers substitute capital equipment for higher-cost labor. Some negative results for Mexico and the United States would follow the implementation of tighter rules of origin in the textiles and apparel sectors. (Canada is less affected due to the leeway provided by its low TPL fill rates.) The effects of increased U.S. access to the Canadian supply-managed dairy market would be very small and macroeconomically insignificant.

The three countries would gain much from ending the dispute triggered by the U.S. tariffs on steel and aluminum. USMCA scenario is extended to include the removal of U.S. steel and aluminum tariffs and a reciprocal elimination of Canadian and Mexican retaliatory import surtaxes. The extension would increase the welfare gain for the Canada, Mexico and the United States by $\$ 2.5$ billion, to a total of $\$ 3$ billion, generate a small increase in GDP in Canada, and help to offset the negative wage impacts of the RVC and LVC provisions on Mexican workers. 
Both the main scenario and the sensitivity analyses highlight the importance of the assumption related to the effects of trade facilitation in determining the magnitude of the overall impact of changes in trade policy. While the empirical literature has made strides in quantifying the effects of non-tariff trade costs on trade flows, assumptions related to these costs remain a key source of uncertainty around model-based estimates of the effects of changes in trade policy. In general, the effects of policy changes in models of the type used in this paper tend to be small when the models describe fixed trade costs and trade efficiency, and a fixed resource base of land, labor and capital. The results show larger aggregate impacts when non-tariff efficiency gains are assumed to be greater than the conservative estimate used in this analysis.

Another important caveat to this analysis is that many aspects of USMCA are not examined due to either modeling limitations or significant uncertainty about their qualitative and quantitative effects. Undoubtedly, these limitations and uncertainties will decline over time following the implementation of USMCA, allowing a more complete analysis of all aspects of the agreement for future work. 


\section{REFERENCES}

Aguiar, Angel (2016). "Concordances - Six Digit HS Sectors to GTAP Sectors." GTAP Resource \#5111. Center for Global Trade Analysis, Purdue University, West Lafayette, IN.

Anson, Jose, Olivier Cadot, Antoni Estevadeordal, Jaime de Melo, Akiko Suwa-Eisenmann and Bolorma Tumurchudur (2005). "Rules of Origin in North-South Preferential Trading Arrangements with an Application to NAFTA," in Review of International Economics, v. 13, no. 3, pp. 501-517.

Bureau of Labor Statistics, U.S. Department of Labor. Automotive Industry: Employment, Earnings and Hours. Accessed on February 5, 2018.

Congressional Research Service (2018). IN FOCUS: Agricultural Provisions of the U.S.Mexico-Canada Agreement. Washington, DC.

Congressional Research Service (2017). Renegotiating NAFTA and U.S. Textile Manufacturing. Washington, DC.

China Ministry of Commerce. Tariff Retaliation List, August 8, 2018. Accessed on August 8, 2018 .

Coalition of American Metal Manufacturers and Users (2018). A Comprehensive List of Reciprocal Tariffs: Last Updated July 11, 2018. Accessed July 31, 2018.

Corong, Erwin L., Thomas W. Hertel, Robert McDougall, Marinos E. Tsigas and Dominique van der Mensbrugghe (2017). "The Standard GTAP Model, Version 7," in Journal of Global Economic Analysis, v. 2, no. 1, p. 1-119.

Costinot, Arnaud and Andres, Rodriguez-Clare (2014). Trade Theory with Numbers:

Quantifying the Consequences of Globalization, in Handbook of International Economics, vol 4, Elsevier.

Dziczek, K., Schultz, M., Chen, Y., \& Swiecki, B. (2018). NAFTA Briefing: Review of Current NAFTA Proposals and Potential Impacts on the North American Automotive Industry. Center for Automotive Research, Ann Arbor, MI.

Eurostat. Annual Detailed Enterprise Statistics on Manufacturing. Accessed February 5, 2018.

Fontagne, Lionel, Cristina Mitaritonna and Jose Signoret (2016). Estimated Equivalents of Service NTMs. No. 16-20, CEPII, Paris, France.

Global Affairs Canada. Export and Import Control System. Accessed on January 6, 2019.

Government of Canada. Canadian Industry Statistics. Accessed February 5, 2018 
Hertel, Thomas W. and Marinos Tsigas (1997)/ "Structure of GTAP," in Thomas W. Hertel, ed. Global Trade Analysis - Modeling and Applications. Cambridge University Press.

Hillberry, Russel and Zhang, Xiaohui (2015). Policy and Performance in Customs: Evaluating the Trade Facilitation Agreement. Policy Research Working Paper;No. 7211. World Bank Group, Washington, DC.

Horridge, Mark (2008). SplitCom-Programs to Disaggregate a GTAP Sector. Center of Policy Studies, Monash University, Australia.

Horridge, Mark, David LaBorde and Janine Pelikan (2018). TASTE: Tariff Analytical and Simulation Tool for Economists. Center for Global Trade Analysis, Purdue University, West Lafayette, IN. Accessed February 16, 2018.

Hufbauer, Gary Clyde and Euijin Jung (w2018). Higher De Minimis Thresholds: A Win in the USMCA. Peterson Institute of International Economics, Washington, DC.

Ibisworld. Automobile Manufacturing in China. Report no. 3721. Accessed on February 3, 2018.

Ibisworld. Auto Parts Manufacturing in China. Report no. 3725. Accessed on February 3, 2018.

International Organization of Motor Vehicle Manufacturers. Production Statistics, 2018. Accessed on February 5, 2018.

Japan Ministry of Economy, Trade and Industry (MITI). Census of Manufactures, 2014. Tokyo, Japan. Accessed on February 6, 2016

Library of the European Parliament (2013). Library Briefing: A Picture of the EU Car Industry. Accessed February 1, 2018.

Ministry of Economy and Pro-Mexico (2016). Mexican Automotive Industry: Current Situation, Challenges and Opportunities. Mexico City, Mexico. Accessed February 23, 2018.

National Bureau of Statistics of China. China Statistical Yearbook, 2016. Accessed February 9, 2018.

Schott, Jeffrey (2018). For Mexico, Canada, and the United States, a Step Backwards on Trade and Investment. Peterson Institute of International Economics. Accessed November 12, 2018.

Spak, Gregory, Francisco de Rosenzweig, Dean A. Barclay, Scott S. Lincicome, Matt Solomon, Brian Picone. Overview of Chapter 7 (Customs Administration and Trade Facilitation) of the US-Mexico-Canada Agreement. Accessed November 23, 2018. 
Statista (2018). Automotive Manufacturing Plant Workers' Median Hourly Salary in 2015, Worldwide by Major Country (in U.S. dollars). Accessed November 1, 2018.

United States Census Bureau. Statistical Abstract of the United States, 2012. Accessed February 5, 2018.

United States Census Bureau. Annual Survey of Manufactures, 2016 Accessed February 4, 2018.

United States Customs and Border Protection. Commodity Status Reports. Accessed January 3, 2019.

United States International Trade Administration, U.S. Department of Commerce (2017). Mexico: Automotive Parts and Supplies. Accessed February 5, 2018.

United States International Trade Administration, U.S. Department of Commerce (2017). China: Automotive Industry. Accessed February 6, 2018.

United States Trade Representative (2018a) List 1 - Tariffs Collected on Imports from China as of July 6,2018. Accessed August 1, 2018.

United States Trade Representative (2018b). List 2 - Tariffs Collected on Imports from China as of August 7, 2018 Accessed August 8, 2018.

United States Trade Representative (2018c). United States-Mexico-Canada Trade Fact Sheet Agriculture: Market Access and Dairy Outcomes of the USMC Agreement. Accessed October 26, 2018.

United States Trade Representative (2018d). United States-Mexico-Canada Trade Fact Sheet Modernizing NAFTA into a 21st Century Trade Agreement Accessed October 26, 2018.

United States Trade Representative (2018e). United States-Mexico-Canada Trade Fact Sheet Rebalancing Trade to Support Manufacturing Accessed October 28, 2018.

United States International Trade Commission (2016). Trans-Pacific Partnership Agreement: Likely Impact on the U.S. Economy and on Specific Industry Sectors. Publication Number: 4607 Investigation Number: TPA-105-001. Washington, DC.

World Integrated Trade Solution (WITS). Accessed February 16, 2018. 
VIII. APPENDIX 


\begin{tabular}{|c|c|c|c|}
\hline \multicolumn{4}{|c|}{ Appendix Table 1. Sectors in the CGE Model ${ }^{1 /}$} \\
\hline Sector & Description & Sector & Description \\
\hline \multirow[t]{5}{*}{ 1. $\quad$ Crops } & \multirow{5}{*}{$\begin{array}{l}\text { Paddy rice } \\
\text { Wheat } \\
\text { Cereal grains nec } \\
\text { Vegetables, fruit, nuts } \\
\text { Oil seeds } \\
\text { Sugar cane, sugar beet } \\
\text { Plant-based fibers } \\
\text { Crops, nec }\end{array}$} & $\begin{array}{l}\text { 10. Petroleum and } \\
\text { coal products }\end{array}$ & $\begin{array}{l}\text { Petroleum, coal products } \\
\text { Chemical, rubber, plastic } \\
\text { prods } \\
\text { Mineral products nec }\end{array}$ \\
\hline & & 11. Motor vehicles & Motor vehicles \\
\hline & & $\begin{array}{l}\text { 12. Motor vehicle } \\
\text { parts }\end{array}$ & Motor vehicle parts \\
\hline & & $\begin{array}{l}\text { 13. Electronic } \\
\text { equipment }\end{array}$ & Electronic equipment \\
\hline & & $\begin{array}{l}\text { 14. Machinery and } \\
\text { equipment, nec }\end{array}$ & $\begin{array}{l}\text { Transport equipment nec } \\
\text { Machinery and equipment } \\
\text { nec }\end{array}$ \\
\hline 2. $\quad$ Livestock & $\begin{array}{l}\text { Cattle, sheep, goats, } \\
\text { horses } \\
\text { Animal products, nec } \\
\text { Raw milk } \\
\text { Wool, silk-worm } \\
\text { cocoons }\end{array}$ & $\begin{array}{l}\text { 15. Manufactures, } \\
\text { nec }\end{array}$ & $\begin{array}{l}\text { Leather products } \\
\text { Ferrous metals } \\
\text { Metals nec } \\
\text { Metal products }\end{array}$ \\
\hline 3. Dairy products & $\begin{array}{l}\text { Milk, butter, cheese, } \\
\text { yoghurt, dried milk } \\
\text { products, whey }\end{array}$ & & Manufactures nec \\
\hline \multirow[t]{2}{*}{ 4. $\quad$ Processed foods } & \multirow{2}{*}{$\begin{array}{l}\text { Meat from cattle, } \\
\text { sheep, etc. } \\
\text { Meat products nec } \\
\text { Vegetable oils and fats } \\
\text { Processed rice } \\
\text { Sugar } \\
\text { Food products nec } \\
\text { Beverages and tobacco } \\
\text { products }\end{array}$} & $\begin{array}{l}\text { 16. Finance and } \\
\text { insurance }\end{array}$ & $\begin{array}{l}\text { Financial services } \\
\text { Insurance }\end{array}$ \\
\hline & & \multirow[t]{6}{*}{ 17. Other services } & \multirow{6}{*}{$\begin{array}{l}\text { Electricity } \\
\text { Gas manufacture, } \\
\text { distribution } \\
\text { Water } \\
\text { Construction } \\
\text { Trade } \\
\text { Transport nec } \\
\text { Sea transport } \\
\text { Air transport } \\
\text { Communication } \\
\text { Business services nec } \\
\text { Recreation and other } \\
\text { services } \\
\text { PubAdmin/Defence/Health } \\
\text { /Ed } \\
\text { Dwellings }\end{array}$} \\
\hline 5. $\quad$ Resources & $\begin{array}{l}\text { Forestry } \\
\text { Fishing } \\
\text { Coal } \\
\text { Oil } \\
\text { Gas } \\
\text { Minerals nec }\end{array}$ & & \\
\hline 6. Textiles & Textiles & & \\
\hline 7. Wearing apparel & Wearing apparel & & \\
\hline 8. Wood products & Wood products & & \\
\hline $\begin{array}{l}\text { 9. Paper products, } \\
\text { publishing }\end{array}$ & $\begin{array}{l}\text { Paper products, } \\
\text { publishing }\end{array}$ & & \\
\hline
\end{tabular}




\begin{tabular}{|c|l|}
\hline \multicolumn{2}{|c|}{ Appendix Table 2. Regional Aggregation in the CGE Model } \\
\hline Canada & Canada \\
\hline United States & United States of America \\
\hline Mexico & Mexico \\
\hline China & China; Hong Kong \\
\hline \multirow{2}{*}{ Other Asia } & $\begin{array}{l}\text { Australia; New Zealand; Rest of Oceania; Japan; Korea; Mongolia; Taiwan; Rest of East } \\
\text { Asia; Brunei Darussalam; Cambodia; Indonesia; Lao People's Democratic Republic; } \\
\text { Malaysia; Philippines; Singapore; Thailand; Viet Nam; Rest of Southeast Asia; } \\
\text { Bangladesh; India; Nepal; Pakistan; Sri Lanka; Rest of South Asia }\end{array}$ \\
\hline \multirow{2}{*}{ EU-27 } & $\begin{array}{l}\text { Austria; Belgium; Cyprus; Czech Republic; Denmark; Estonia; Finland; France; } \\
\text { Germany; Greece; Hungary; Ireland; Italy; Latvia; Lithuania; Luxembourg; Malta; } \\
\text { Netherlands; Poland; Portugal; Slovakia; Slovenia; Spain; Sweden; Bulgaria; Croatia; } \\
\text { Romania }\end{array}$ \\
\hline $\begin{array}{l}\text { Rest of North America; Argentina; Bolivia; Brazil; Chile; Colombia; Ecuador; Paraguay; } \\
\text { Peru; Uruguay; Venezuela; Rest of South America; Costa Rica; Guatemala; Honduras; } \\
\text { Nicaragua; Panama; El Salvador; Rest of Central America; Dominican Republic; } \\
\text { Jamaica; Puerto Rico; Trinidad and Tobago; Caribbean; United Kingdom; Switzerland; } \\
\text { Norway; Rest of EFTA; Albania; Belarus; Russian Federation; Ukraine; Rest of Eastern } \\
\text { Europe; Rest of Europe; Kazakhstan; Kyrgyzstan; Tajikistan; Rest of Former Soviet } \\
\text { Union; Armenia; Azerbaijan; Georgia; Bahrain; Iran Islamic Republic of; Israel; Jordan; } \\
\text { Kuwait; Oman; Qatar; Saudi Arabia; Turkey; United Arab Emirates; Rest of Western } \\
\text { Asia; Egypt; Morocco; Tunisia; Rest of North Africa; Benin; Burkina Faso; Cameroon; } \\
\text { Cote d'Ivoire; Ghana; Guinea; Nigeria; Senegal; Togo; Rest of Western Africa; Central } \\
\text { Africa; South Central Africa; Ethiopia; Kenya; Madagascar; Malawi; Mauritius; } \\
\text { Mozambique; Rwanda; Tanzania; Uganda; Zambia; Zimbabwe; Rest of Eastern Africa; } \\
\text { Botswana; Namibia; South Africa; Rest of South African Customs ; Rest of the World }\end{array}$ \\
\hline
\end{tabular}




\begin{tabular}{|c|c|c|c|c|c|c|c|c|c|}
\hline \multicolumn{10}{|c|}{ Appendix Table 3. Base Value of Bilateral Exports (\$US millions) } \\
\hline & \multicolumn{3}{|c|}{ Canada exports to: } & \multicolumn{3}{|c|}{ Mexico exports to: } & \multicolumn{3}{|c|}{ United States exports to: } \\
\hline & Mexico & USA & ROW & Canada & USA & ROW & Canada & Mexico & ROW \\
\hline Crops & 1,083 & 4,414 & 17,479 & 1,226 & 9,098 & 1,804 & 6,174 & 7,652 & 48,548 \\
\hline Livestock & 10 & 2,708 & 996 & 1 & 864 & 144 & 717 & 553 & 3,844 \\
\hline Dairy & 14 & 113 & 237 & 2 & 100 & 67 & 295 & 1,228 & 3,288 \\
\hline Food mfg. & 897 & 17,264 & 8,136 & 537 & 10,493 & 4,256 & 16,261 & 10,534 & 43,053 \\
\hline Natural Res. & 97 & 75,171 & 17,826 & 1,041 & 47,473 & 13,333 & 9,523 & 7,286 & 20,474 \\
\hline Textiles & 146 & 1,254 & 432 & 100 & 1,590 & 626 & 2,521 & 4,082 & 9,229 \\
\hline Apparel & 4 & 657 & 239 & 340 & 3,678 & 309 & 956 & 517 & 2,774 \\
\hline Lumber & 54 & 8,361 & 3,341 & 22 & 293 & 30 & 1,912 & 695 & 4,811 \\
\hline Paper/publ. & 287 & 10,278 & 6,595 & 145 & 1,515 & 792 & 8,425 & 5,343 & 19,918 \\
\hline Petrol/coal & 1,722 & 47,203 & 14,517 & 1,395 & 17,513 & 13,184 & 59,873 & 61,479 & 274,607 \\
\hline $\begin{array}{l}\text { Motor } \\
\text { vehicles } \\
\end{array}$ & 822 & 44,665 & 2,529 & 4,557 & 31,526 & 9,666 & 28,356 & 6,731 & 35,924 \\
\hline $\begin{array}{l}\text { Vehicle } \\
\text { parts }\end{array}$ & 1,066 & 13,935 & 1,214 & 5,214 & 40,887 & 4,457 & 28,501 & 20,013 & 18,006 \\
\hline $\begin{array}{l}\text { Electr. } \\
\text { Equip. }\end{array}$ & 767 & 6,005 & 5,120 & 6,057 & 47,840 & 11,839 & 15,851 & 15,759 & 115,913 \\
\hline $\begin{array}{l}\text { Machinery } \\
\text { nec }\end{array}$ & 1,078 & 30,910 & 15,349 & 5,813 & 59,261 & 9,686 & 50,585 & 44,924 & 219,483 \\
\hline Mfg. nec & 2,272 & 27,566 & 19,236 & 3,093 & 28,205 & 10,037 & 21,963 & 18,060 & 99,895 \\
\hline Finance/ins. & 46 & 3,537 & 4,219 & 10 & 376 & 2,078 & 5,044 & 823 & 49,371 \\
\hline $\begin{array}{l}\begin{array}{l}\text { Other } \\
\text { services }\end{array} \\
\end{array}$ & 95 & 11,407 & 40,077 & 78 & 3,108 & 6,201 & 14,410 & 2,985 & 242,533 \\
\hline Total & 10,461 & 305,448 & 157,541 & 29,631 & 303,820 & 88,508 & 271,368 & 208,664 & $1,211,670$ \\
\hline
\end{tabular}




\begin{tabular}{|c|c|c|c|c|c|c|c|c|c|c|}
\hline \multicolumn{11}{|c|}{ Appendix Table 4. Base Tariff Rates in the USMCA } \\
\hline & \multicolumn{3}{|c|}{ Canada } & \multicolumn{3}{|c|}{ Mexico } & \multicolumn{4}{|c|}{ United States } \\
\hline & $\begin{array}{c}\text { NAFTA } \\
\text { rate on } \\
\text { Mexico }\end{array}$ & $\begin{array}{l}\text { NAFTA } \\
\text { rate on } \\
\text { U.S. }\end{array}$ & $\begin{array}{l}\text { NAFTA plus } \\
\text { reciprocal } \\
\text { rate on U.S. }\end{array}$ & $\begin{array}{c}\text { NAFTA } \\
\text { rate on } \\
\text { Canada }\end{array}$ & $\begin{array}{l}\text { NAFTA } \\
\text { rate on } \\
\text { U.S. }\end{array}$ & $\begin{array}{l}\text { NAFTA plus } \\
\text { reciprocal } \\
\text { rate on U.S. }\end{array}$ & $\begin{array}{c}\text { NAFTA } \\
\text { rate on } \\
\text { Canada }\end{array}$ & $\begin{array}{l}\text { NAFTA rate } \\
\text { plus steel/alum. } \\
\text { tariffs on } \\
\text { Canada }\end{array}$ & $\begin{array}{l}\text { NAFTA } \\
\text { rate on } \\
\text { Mexico }\end{array}$ & $\begin{array}{l}\text { NAFTA rate } \\
\text { plus steel/alum. } \\
\text { tariffs on } \\
\text { Mexico }\end{array}$ \\
\hline Crops & 0.0 & 0.0 & 0.0 & 0.0 & 0.0 & 0.8 & 0.0 & 0.0 & 0.0 & 0.0 \\
\hline Livestock & 0.0 & 0.0 & 0.0 & 0.0 & 0.0 & 0.0 & 0.0 & 0.0 & 0.0 & 0.0 \\
\hline Dairy & 4.7 & 13.8 & 14.0 & 6.2 & 0.0 & 5.3 & 4.5 & 4.5 & 0.0 & 0.1 \\
\hline Food mfg. & 0.0 & 0.0 & 1.9 & 0.0 & 0.0 & 3.1 & 1.1 & 1.1 & 0.0 & 0.2 \\
\hline Natural resources & 0.0 & 0.0 & 0.0 & 0.0 & 0.0 & 0.0 & 0.0 & 0.0 & 0.0 & 0.0 \\
\hline Textiles & 0.0 & 0.0 & 0.4 & 0.0 & 0.0 & 0.0 & 0.0 & 0.0 & 0.0 & 0.0 \\
\hline Apparel & 0.0 & 0.0 & 0.0 & 0.0 & 0.0 & 0.0 & 0.0 & 0.0 & 0.0 & 0.0 \\
\hline Lumber & 0.0 & 0.0 & 1.1 & 0.0 & 0.0 & 0.6 & 0.0 & 0.0 & 0.0 & 0.0 \\
\hline Paper and prods. & 0.0 & 0.0 & 0.0 & 0.0 & 0.0 & 0.0 & 0.0 & 0.0 & 0.0 & 0.0 \\
\hline Petro/chem & 0.0 & 0.0 & 0.5 & 0.0 & 0.0 & 0.0 & 0.0 & 0.0 & 0.0 & 0.0 \\
\hline Motor vehicles & 0.0 & 0.0 & 0.0 & 0.0 & 0.0 & 0.0 & 0.0 & 0.0 & 0.0 & 0.0 \\
\hline Motor vehicle parts & 0.0 & 0.0 & 0.0 & 0.0 & 0.0 & 0.0 & 0.0 & 0.0 & 0.0 & 0.0 \\
\hline Elect. equip. & 0.0 & 0.0 & 0.0 & 0.0 & 0.0 & 0.0 & 0.0 & 0.0 & 0.0 & 0.0 \\
\hline Machinery nec. & 0.0 & 0.0 & 0.3 & 0.0 & 0.0 & 0.0 & 0.0 & 0.0 & 0.0 & 0.0 \\
\hline MFG nec. & 0.0 & 0.0 & 7.8 & 0.0 & 0.0 & 7.5 & 0.0 & 6.3 & 0.0 & 3.7 \\
\hline Weighted. avg. tariff & 0.0 & 0.0 & 1.2 & 0.0 & 0.0 & 1.0 & 0.1 & 0.9 & 0.0 & 0.3 \\
\hline
\end{tabular}




\begin{tabular}{|l|r|r|r|r|r|r|}
\hline \multicolumn{7}{|c|}{ Appendix Table 5. Welfare and real GDP effects of USMCA - Sensitivity with a .5\% Increase in } \\
Trade Efficiency \\
\hline
\end{tabular}




\begin{tabular}{|c|c|c|c|c|c|c|c|}
\hline \multicolumn{8}{|c|}{$\begin{array}{c}\text { Appendix Table 6. Welfare and real GDP effects of USMCA - Sensitivity with a } 0.1 \% \text { Increase in Canada and U.S. } \\
\text { Trade Efficiency, and } 0.5 \% \text { to } 2.0 \% \text { Increase in Mexico Trade Efficiency }\end{array}$} \\
\hline & \multicolumn{2}{|c|}{ Vehicles and parts } & \multirow{2}{*}{$\begin{array}{c}\text { Textile } \\
\text { /apparel } \\
\text { ROOs }\end{array}$} & \multirow[t]{2}{*}{ Agriculture } & \multirow{2}{*}{$\begin{array}{l}\text { Trade } \\
\text { facilitation }\end{array}$} & \multirow{2}{*}{$\begin{array}{l}\text { Steel tariff } \\
\text { /surtax } \\
\text { reforms }\end{array}$} & \multirow[t]{2}{*}{ Total } \\
\hline & RVC & LVC & & & & & \\
\hline \multicolumn{8}{|c|}{ Welfare changes (\$US million) } \\
\hline \multicolumn{8}{|c|}{0.5 percent increase in Mexico trade efficiency } \\
\hline Canada & 171.9 & -40.45 & 4.12 & 138.56 & 466.45 & 494.06 & $1,234.59$ \\
\hline USA & -739.9 & -380.40 & -56.53 & -85.23 & 915.88 & $2,094.11$ & $1,747.97$ \\
\hline Mexico & -13.9 & 331.86 & -111.09 & 2.74 & $1,061.05$ & -48.67 & $1,222.01$ \\
\hline \multicolumn{8}{|c|}{ 1.0 percent increase in Mexico trade efficiency } \\
\hline Canada & 171.8 & -40.46 & 4.12 & 138.56 & 474.35 & 493.88 & $1,242.29$ \\
\hline USA & -740.1 & -380.61 & -56.53 & -85.23 & $1,475.18$ & $2,097.60$ & $2,310.33$ \\
\hline Mexico & -13.92 & 331.85 & -111.00 & 2.74 & $1,908.61$ & -50.68 & $2,067.60$ \\
\hline \multicolumn{8}{|c|}{ 1.5 percent increase in Mexico trade efficiency } \\
\hline Canada & 171.8 & -40.47 & 4.12 & 138.56 & 482.39 & 493.70 & $1,250.13$ \\
\hline USA & -740.3 & -380.83 & -56.53 & -85.23 & $2,033.17$ & $2,101.09$ & $2,871.37$ \\
\hline Mexico & -13.96 & 331.84 & -110.90 & 2.74 & $2,762.64$ & -52.68 & $2,919.68$ \\
\hline \multicolumn{8}{|c|}{2 percent increase in Mexico trade efficiency } \\
\hline Canada & 171.8 & -40.48 & 4.13 & 138.56 & 490.60 & 493.52 & $1,258.15$ \\
\hline USA & -740.5 & -381.04 & -56.53 & -85.23 & $2,589.68$ & $2,104.58$ & $3,430.94$ \\
\hline Mexico & -14.00 & 331.83 & -110.81 & 2.74 & $3,623.07$ & -54.68 & $3,778.15$ \\
\hline \multicolumn{8}{|c|}{ Real GDP effects (percent change from base) } \\
\hline \multicolumn{8}{|c|}{0.5 percent increase in Mexico trade efficiency } \\
\hline Canada & 0.00 & 0.00 & 0.00 & 0.00 & 0.02 & 0.02 & 0.04 \\
\hline USA & 0.00 & 0.00 & 0.00 & 0.00 & 0.00 & 0.00 & 0.00 \\
\hline Mexico & -0.01 & -0.01 & 0.00 & 0.00 & 0.07 & 0.00 & 0.05 \\
\hline \multicolumn{8}{|c|}{ 1.0 percent increase in Mexico trade efficiency } \\
\hline Canada & 0.00 & 0.00 & 0.00 & 0.00 & 0.02 & 0.02 & 0.04 \\
\hline USA & 0.00 & 0.00 & 0.00 & 0.00 & 0.00 & 0.00 & 0.00 \\
\hline Mexico & -0.01 & -0.01 & 0.00 & 0.00 & 0.13 & 0.00 & 0.11 \\
\hline \multicolumn{8}{|c|}{1.5 percent increase in Mexico trade efficiency } \\
\hline Canada & 0.00 & 0.00 & 0.00 & 0.00 & 0.02 & 0.02 & 0.04 \\
\hline USA & 0.00 & 0.00 & 0.00 & 0.00 & 0.00 & 0.00 & 0.00 \\
\hline Mexico & -0.01 & -0.01 & 0.00 & 0.00 & 0.20 & 0.00 & 0.18 \\
\hline \multicolumn{8}{|c|}{2 percent increase in Mexico trade efficiency } \\
\hline Canada & 0.00 & 0.00 & 0.00 & 0.00 & 0.02 & 0.02 & 0.04 \\
\hline USA & 0.00 & 0.00 & 0.00 & 0.00 & 0.00 & 0.00 & 0.00 \\
\hline Mexico & -0.01 & -0.01 & 0.00 & 0.00 & 0.27 & 0.00 & 0.25 \\
\hline
\end{tabular}

